\title{
Floppy eyelid syndrome associated with keratotorus
}

\author{
ALEKSANDAR PARUNOVIĆ AND BOŽIDAR ILIĆ \\ From the University Eye Clinic, Belgrade, Yugoslavia
}

SUMmARY A case of floppy eyelid syndrome associated with keratotorus is presented. The patient was thoroughly examined and followed up for several years. During that time he developed an acute corneal hydrops. The importance of this association for the better understanding of the syndrome is discussed.

The floppy eyelid syndrome is a fairly newly recognised clinical entity of so far unknown aetiology. The first authors to describe it ${ }^{2}$ noted the association of the syndrome with other ocular or systemic disorders. We report here on a patient who has had floppy eyelids associated with a specific corneal ectasia-keratotorus.

\section{Case report}

A 54-year-old man was seen for the first time at the University Eye Clinic in 1961. Stanković and

Correspondence to A Parunović, Očna klinika, Pasterova 2, 1100() Belgrade, Yugoslavia.

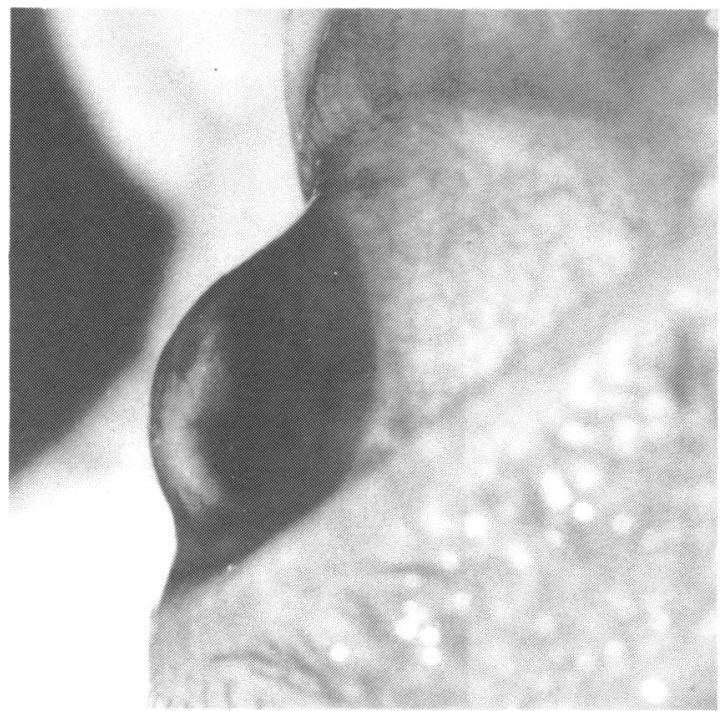

Fig. 1 Acute keratotorus with everted floppy eyelid.
Stankovic published a detailed description of this case. ${ }^{3} \mathrm{He}$ had a typical bilateral keratotorus with myopic astigmatism against the rule and clear pyriform ectatic cornea. No changes in the lids were recorded.

In 1985 he presented to us with a red, inflamed right eye together with acute oedema of the ectatic part of the cornea. The cornea of the left eye was clear, with typical unchanged keratotorus. There was a punctate keratopathy of the entire corneal surface in both eyes. The upper eye lids could be easily everted and pulled up. The palpebral conjunctiva of the upper lid, especially in the right eye, showed a

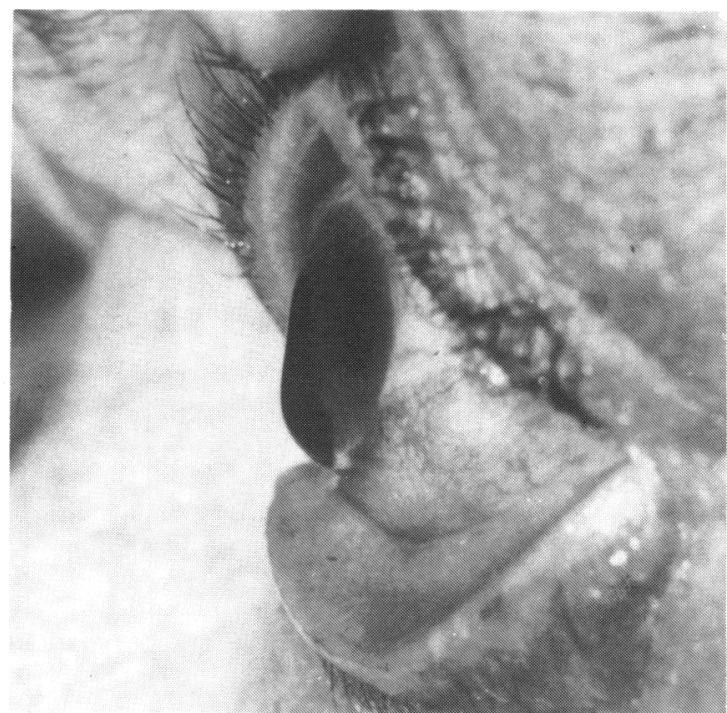

Fig. 2 Keratotorus in the left eye. 
marked papillary hypertrophy. The patient was not obese.

Local corticosteroids were administered, and after two weeks the corneal oedema as well as the inflammatory reaction almost disappeared.

In the next few months the eye was quiet and the corneal oedema resolved, but the scar in the central ectatic part continued to show a typical pyriform ectasia. The patient refused any type of surgery.

\section{Discussion}

The first recognised association of the floppy eyelid syndrome was with obesity and nocturnal lagophthalmos, ${ }^{12}$ later with hyperglycinaemia, ${ }^{4}$ blepharochalasis, ${ }^{5}$ and tapetoretinal degeneration. ${ }^{6}$ There has been only one report on the association of floppy eyelid with keratoconus ${ }^{6}$ but not a single one with keratotorus, or acute hydrops of the cornea. It is true, however, that there is no unanimity of opinion on the relation of keratoconus and keratotorus with pellucidal marginal degeneration. Most European ophthalmologists ${ }^{37 \times}$ regard them as distinct clinical entities, but some American authors consider clinically different corneal protrusions to be variants of one and the same condition. ${ }^{4}$ Whichever is correct, the floppy eyelid syndrome in our patient was associated with acute hydrops of an unusually ectatic cornea (keratotorus).

There are two theories about the possible aetiology of the floppy eyelid syndrome. It is either the result of a partial nocturnal lagophthalmos or an ocular manifestation of a so far unknown systemic disorder. The case we describe here seems to support the latter theory. We have already seen a patient with both keratoconus and floppy eyelids, and similar observations have been reported. ${ }^{6}$ However, there has always been plenty of evidence of the association of keratoconus with many systemic diseases, to mention only Down's syndrome endocrine disorders, and atopic disease.

\section{References}

1 Culbertson WW, Ostler HB. The floppy eyelid syndrome. Am J Ophthalmol 1981; 92: 568-75.

2 Parunović A. Floppy eyelid syndrome. Br J Ophthalmol 1983; 67: 264-6.

3 Stanković I, Stanković M. Ein Beitrag zur Kenntnis der Keratotorus. Klin Monatsbl Augenheilkd 1966; 148: 873-80.

4 Gerner EW, Hughes SM. Floppy eyelid with hyperglycinemia. Am J Ophthalmol 1984; 98: 614-6.

5 Goldberg R, Seiff S, McForland J, et al. Floppy eyelid syndrome and blepharochalasis. Am J Ophthalmol 1986; 102: 376-81.

6 Huber-Spitzy V, Grabner G, Stur M, Das Syndrom des Schlaffenoberlides. Klin Monatsbl Augenheilkd 1984; 185: 289-91.

7 Hallerman W. Über atipishen Keratoconus und andere konstitutionell progressive Hornhautectasien. Klin Monatsbl Augenheilkd 1970; 156: 161-73.

8 François J, Hassens M, Stockmans L. Dégénérescence marginale pellucide de la cornée. Ophthalmologica 1968; 155: 337-56.

9 Grayson M. Diseases of the cornea. St Louis: Mosby. 1979: 260.

Accepted for publication 18 May 1987. 